\title{
„NARCYZ BEZ TWARZY?" POSTKOLONIALNE OBLICZA DANILA KIŠA
}

\author{
SYLWIA NOWAK-BAJCAR ${ }^{1}$ \\ (Uniwersytet Jagielloński)
}

\begin{abstract}
Słowa kluczowe: Danilo Kiš, zaangażowanie, postmodernizm, etyczna poetyka jako po-etyka, forma, kanon
\end{abstract}

Key words: Danilo Kiš, commitment, postmodernism, ethical poetics as po-ethics, form, canon

\begin{abstract}
Abstrakt: Sylwia Nowak-Bajcar, „NARCYZ BEZ TWARZY?” POSTKOLONIALNE OBLICZA DANILA KIŠA. „PORÓWNANIA” 14, 2014, T. XIV, s. 71-82. ISSN 1733-165X. Zarówno w czasach Jugosławii, jak i po jej rozpadzie, kluczową kategorią dla odczytań twórczości Danila Kiša stała się kategoria zaangażowania. To ona, uzasadniając jego status ikony pisarstwa środkowoeuropejskiego, okazała się punktem odniesienia dla toczących się wokół postaci pisarza dyskusji, związanych z istnieniem w Serbii postmodernizmu. Historia ataków na Kiša dopełniona zostanie najnowszymi, postkolonialnymi, inicjowanymi także z pozycji "zaangażowania", rewizjami oceny dorobku twórcy. Zaprezentowane sposoby „użycia” wizerunku i twórczości Kiša potwierdzają tezę Gayatri Chakravorty Spivak o tym, że etyczny cel badań postkolonialnych jest w zasadzie „doświadczaniem niemożliwego".
\end{abstract}

\begin{abstract}
Sylwia Nowak-Bajcar, „A NARCISSIST WITHOUT A FACE?” POSTCOLONIAL COUNTENANCES OF DANILO KIŠ. „PORÓWNANIA” 14, 2014, Vol. XIV, p. 71-82. ISSN 1733165X. Both in the days of Yugoslavia as well as after its collapse commitment has become the key category for reading Danilo Kiš's works. It is exactly the category of the ethical commitment that became the point of reference of discussions about the writer associated with the existence of postmodernism in Serbia. It is also the same category that established Kiš's status as one of the most noted writers of Central and Eastern Europe. The history of attacks on Kiš will be supplemented with the newest postcolonial reinterpretations of his achievements initiated from the position of "commitment". The presented ways of using Kišs image and his artistic work confirm the Gayatri Chakravorty Spivak's thesis that ethical purpose of postcolonial research is in fact "experiencing the impossible".
\end{abstract}

\footnotetext{
${ }^{1}$ Correspondence Address: s.nowak-bajcar@uj.edu.pl
} 
W obliczu intensyfikacji przemian społeczno-polityczno-kulturowych, które $\mathrm{w}$ ostatnich dziesięcioleciach dotykały Serbii (mam tu na myśli ostatnie wojny na Bałkanach, okres rewolucji w październiku 2000 roku, kiedy obalono reżim Slobodana Miloševicia, a obecnie - zamiary przystąpienia Serbii do UE), w jej życiu kulturalnym bardzo wyraźnie ujawniła się potrzeba przebudowy kanonu literackiego, który zadowalałby ambicje serbskiej wspólnoty narodowej i jednocześnie potwierdzał europejskie aspiracje tej kultury. Niezwykłym w tym kontekście wydaje się fakt, że procesowi rewaloryzacji kanonu nie poddano dzieł pisarzy, których twórczość - z wielu względów, od artystycznych poczynając, na ideologicznych kończąc - niemal sama się o to dopomina), lecz Danila Kiša, twórcy powszechnie uznanego i szanowanego w Europie, którego status ikony pisarstwa środkowoeuropejskiego uzasadniało wielu badaczy, bardzo zaś przekonująco w Polsce Aleksander Fiut w książce pt. Być albo nie być Środkowoeuropejczykiem?2.

Nie jest to, oczywiście, fakt, który mógłby zaskakiwać. Bardzo odległa, sięgająca końca lat siedemdziesiątych XX wieku historia ataków na Kiša zdążyła nas "przyzwyczaić" do takiego sposobu traktowania tego pisarza, potwierdzając jego status wiecznego outsidera. Status ów wyznacza symbolicznie określenie „narcyz bez twarzy", będące tytułem głośnej książki z 1981 roku³. Jej autor, profesor Uniwersytetu Belgradzkiego Dragan Jeremić, występując jako obrońca absolutnej oryginalności twórczej, zdemistyfikował - w swoim, oczywiście, mniemaniu - metodę twórczą Kiša, nazywając ją "plagiatem" i wysuwając pod adresem pisarza oskarżenia o to, że stał się on apologetą kompilacji cudzych myśli i stylu. Książka Jeremicia, będąca zresztą do tej pory jedną z najbardziej wnikliwych naukowych analiz intertekstualnych związków w dziełach Kiša, była jednocześnie dowódem wyrosłego na gruncie formalistycznych przesłanek, całkowitego niezrozumienia istoty i funkcji tych odniesien. Stanowiła zarazem zwieńczenie toczących się przez kilka lat dyskusji wokół stosowanej ostentacyjnie przez Kiša techniki cytatu, będącej wyrazem przekonania o tym, że literatura żywi się literaturą. Publikacja Jeremicia pojawiła się w okresie, kiedy postmodernizm wkraczał już na scenę literacką w Serbii. Była, jak się wydaje z dzisiejszej perspektywy, próbą zdyskredytowania nowych, postmodernistycznych tendencji i obrony realizmu.

Wyeksponowany przez Jeremicia „brak twarzy” (może bardziej wskazane byłoby tu określenie „człowieka bez właściwości”) w symboliczny sposób napiętnował pośmiertny los Kiša, co doskonale uwidacznia się w postkolonialnych (i nie tylko) sposobach interpretowania jego dzieł.

Zarówno w czasach Jugosławii, jak i po jej rozpadzie, kluczową kategorią dla odczytań twórczości Kiša stała się kategoria zaangażowania. To ona, uzasadniając

2 A. Fiut, Paleontologia pamięci (O Danile Kišu). W: Być (albo nie być) Środkowoeuropejczykiem. Kraków 1999, s. 279-302.

${ }^{3}$ D. Jeremić, Narcis bez lica. Beograd 1981. 
status Kiša jako ikony pisarstwa środkowoeuropejskiego, okazała się jednocześnie punktem odniesienia dla toczących się wokół postaci pisarza dyskusji, związanych $\mathrm{z}$ istnieniem postmodernizmu w Serbii. Jego przedstawiciele podczas wspomnianej polemiki z końca lat siedemdziesiątych i początku osiemdziesiątych nie tylko wystąpili w obronie Kiša, ale nawet uznali go za swojego duchowego "przodka"4.

Zaanektowanie przez postmodernistów twórczości Kiša wydaje się zrozumiałe (choć nie do końca uzasadnione, o czym później), bowiem obecne w dziele Kiša tendencje doskonale korespondują z postmodernistyczną i poststrukturalistyczną myślą na temat historii, literatury i kultury. W obecnej w dziełach tego twórcy autopoetyckiej refleksji nad sposobami prezentowania historii postmoderniści dostrzegli echa teorii Haydena White'a (nieobiektywny, fikcjonalny charakter, opartej na podważonym przez niego statusie dokumentu, wiedzy historycznej, która, tracąc swój autorytet, zbliża się do literatury) czy teorii Michela Foucaulta (odejście od wizji historii jako linearnego, ciągłego procesu na rzecz koncepcji historii jako ciągłego strumienia interpretacji). Wyodrębniony w dziełach Kiša krąg tematyczny, związany z refleksją nad Holokaustem i stalinizmem (wykorzystanie przez serbskiego pisarza kategorii świadka) łączono z pracami Shoshany Felman, umieszczano $w$ kontekście rozważań nad kategorią traumy oraz prób przezwyciężenia niemocy wiarygodnego przedstawienia stalinizmu czy Holocaustu Dominicka La Capry5.

Owa rozrachunkowość - dodajmy - choć związana z dokonaną przez Kiša krytyką postaw wobec stalinizmu zachodnioeuropejskiej lewicy nie była jednak na poziomie eksplicytnym wymierzona $\mathrm{w}$ równie opresyjną odmianę rodzimej wersji totalitarnego systemu - titoizm (rozrachunki z titoizmem zaistniały w Serbii w całej pełni dopiero w latach dziewięćdziesiątych XX wieku), choć zarzuty Kiša można, oczywiście, na poziomie aluzyjnym odczytywać jako nawiązania do metod, jakimi posługiwał się Tito. Dodać także należy, że krytyki stalinizmu w Jugosławii dokonywano już od końca lat czterdziestych XX wieku, kiedy to w 1948 roku po tzw. Aferze Biura Informacyjnego zostały zerwane stosunki dyplomatyczne pomiędzy Jugosławią a ZSRR. Rozrachunek Kiša z totalitaryzmem odbywał się $\mathrm{w}$ ramach istniejącego systemu, nie wykraczając poza dopuszczalne granice wolności. Był to rozrachunek ze stalinizmem i ideologią komunistyczną, ale - podkreślmy raz jeszcze - na poziomie eksplicytnym - nie był to rozrachunek z samym titoizmem (taki charakter miał pochodzący z 1989 roku film Aleksandra Mandicia i Kiša Goli život - Nagie życie opisujący biografie i doświadczenia ofiar obozu titoistycznych obozów).

${ }^{4} \mathrm{O}$ tych polemikach pisałam obszernie w książce: Mapy czasu. Serbska proza postmodernistyczna wobec wyzwań epoki. Kraków 2010, s. 67-89.

${ }^{5}$ D. Beganović, O kulturalnom pamćenju u djelu Danila Kiša. „Letopis Matice srpske” 2006, nr 2, s. 187-199. 
Zanim przejdę do postkolonialnych strategii odczytań twórczości Kiša, powrócę jeszcze sposobu postrzegania przez niego zaangażowania, za sprawą którego między innymi - jak wspomniałam - zyskał on status pisarza środkowoeuropejskiego. Za swoisty paradoks należy uznać fakt, że ta właśnie podstawowa kategoria dyskursu postkolonialnego, kategoria umożliwiająca (także Kišowi) wypowiadanie się $\mathrm{w}$ imieniu ofiary, uciskanego, prześladowanego (podmiotu słabego), stała się punktem wyjścia dla sformułowanych pod adresem pisarza zarzutów. $\mathrm{Z}$ tego powodu konieczne jest przybliżenie sformułowanej przez Kiša koncepcji etycznej poetyki, określanej przez niego mianem po-etyki.

W sposobie definiowania przez serbskiego twórcę zaangażowania kluczowa okazuje się twórczość argentyńskiego pisarza Jorge Luisa Borgesa, do dzieł którego Kiš polemicznie nawiązywał. Ów aspekt polemiczny opiera się, jak twierdzi Kiš, na umieszczeniu wykorzystanego $w$ utworach materiału dokumentalnego nie w kontekście symboliczno-metafizycznym (jak u Borgesa), lecz w konkretnym kontekście historycznym.

Tym, czego krytycy nie zauważyli w Grobowcu dla B.D. - stwierdza Kiš - mimo że było to, moim zdaniem, ewidentne, jest fakt "borgesowskiego" sposobu użycia pewnych technik $\mathrm{w}$ odniesieniu do materiału pozornie do nich nieadekwatnego: do fabuł relewantnych historycznie, a nawet politycznie oraz zastąpienie Borgesowskiego solipsyzmu i metafizycznej pozaczasowości (jako programu) ową historycznością i politycznością, co, moim skromnym zdaniem, do pewnego stopnia można uznać za literacką nowość w podejściu do literatury ${ }^{6}$. (podkr. S.N.B).

Kwestia borgesowskiej metafizyki wydaje się dosyć niekonsekwentnie traktowana przez samego Kiša, co najlepiej widać, kiedy w innym miejscu stwierdza on: „Mistrz Borges funduje swój świat na przerażającej metafizycznej pustce, bardzo mi bliskiej." (podkr. S.N.B.) ${ }^{7}$ Bez względu jednak na niezdecydowanie Kiša w kwestii nie/istnienia warstwy metafizycznej w twórczości Borgesa, najważniejszy wydaje się fakt, że $\mathrm{w}$ opisie twórczości argentyńskiego pisarza, dokonanej przez Kiša, nieoczekiwanie staje się ona przeciwieństwem zaangażowania, otrzymując nawet epitet „amoralnej” dokumentalności. W jednej z wypowiedzi Kiš stwierdza:

Pisarzem nie zostaje się po to, jak powiedziałby Sartre, aby pięknie pisać. Jeżeli człowiek dokonuje wyboru literatury, to ta jego decyzja, sama w sobie, bez względu na początkowe motywy tego wyboru, jest wyborem totalnym, i $\mathrm{w}$ takim sensie, i wyłącznie $w$ takim sensie jest to zaangażowanie. Pisanie jest $\mathrm{w}$ istocie $c z y n e m$ humanistycznym: pisarz pragnie uczestniczyć w świecie idei, chociażby pośrednio, aby swoimi

${ }^{6}$ D. Kiš, Čas anatomie. Beograd 1979, s. 12. Fragmenty tłumaczeń wypowiedzi Kiša, o ile nie odnotowano inaczej, podaję we własnym przekładzie.

${ }^{7}$ D. Kiš, Imeđu politike i poetike. W: idem, Gorki talog iskustva, op. cit., s. 208. 
dziełami, swoim życiem, swoim uczestniczeniem, nadać sens swojemu istnieniu, swojemu powołaniu ${ }^{8}$. (Podkreślenia pochodzą od Autora.)

Nie ma wątpliwości, że Kiš pojmuje zaangażowanie jako dawanie całego siebie, jako rodzaj totalnego oddania literaturze (światu idei). I właśnie sposób definiowania przez niego zaangażowania stanowi dowód na to, jak mocno osadzony był on w modernizmie i micie twórcy. Podczas gdy dla Kiša możliwym jest bycie artystą, dla którego praca nad Formą jest tożsama z dawaniem siebie, aby w ten sposób nadać sens swojemu życiu, dla postmodernistów taka humanistyczna akcja nie jest możliwa, podobnie jak nie jest możliwe urzeczywistnienie idei Formy, do której Kiš był bardzo mocno przywiązany, co doskonale widać także w innym fragmencie jego wypowiedzi:

Gdy mówię, że jedną ze wspólnych cech pisarzy proweniencji środkowoeuropejskiej jest świadomość formy, formy jako dążenia do nadania sensu własnemu życiu i metafizycznym dwuznacznościom, formy jako możliwości wyboru, która jest próbą odnalezienia jakiegoś Archimedesowego mocnego punktu w otaczającym nas chaosie, formy, która jest przeciwieństwem barbarzyńskiego rozpadu i irracjonalnej samowoli instynktów - obawiam się, że być może tylko uogólniam w ten sposób własne obsesje intelektualne i literackie?.

Na podstawie wcześniej przywołanych wypowiedzi o Borgesie, wydaje się, że w ramach dawania siebie humanistyczna akcja, o której mówi Kiš, zakłada także określoną postawę wobec ideologii, a więc zaangażowanie pisarza wymagałoby także i takiego rodzaju aktywności. Swoją tezę Kiš popiera twierdzeniem, że biografie kryminalistów w Krótkiej historii nikczemności Borgesa, z którą polemizował, pisząc w 1976 roku Grobowiec dla Borysa Davidowicza są - jak stwierdza - „opowiastkami dla małych dzieci". To twierdzenie można zrozumieć jako oskarżenie o brak zaangażowania (eskapizm), skierowany pod adresem Borgesa (którego przekonania, dodajmy na marginesie, były antykomunistyczne):

Swoją najsłynniejszą książkę - pisze Kiš - Borges opatruje tytułem Powszechna historia nikczemności, ale na planie tematycznym nie jest to żadna „powszechna historia nikczemności“" lecz są to, powtarzam, na planie tematycznym historyjki dla małych dzieci, nieistotne ze społecznego punktu widzenia, o nowojorskich gangsterach, o chińskich piratach, o prowincjonalnych rozbójnikach itp. Zatem w pierwszym rzędzie polemizowałem $\mathrm{z}$ tytułem Borgesa, nieadekwatnym ponad wszelką miarę (co sam zresztą gdzieś przyznał). Ja natomiast twierdzę, że powszechna historia nikczemności to dwudziesty wiek ze swoimi obozami, przede wszystkim sowieckimi. Jest bowiem nikczemnością, gdy w imię idei lepszego świata, za którą umierały generacje, w imię takiej humani-

${ }^{8}$ D. Kiš, Doba sumuje, W: idem, Gorki talog iskustva, op. cit., s. 58.

9 D. Kiš, Homo poeticus, mimo wszystko. Eseje. W: idem, Pisma wybrane, t. 3, wybór, przekład i posłowie D. Cirlić-Straszyńska. Izabelin 1998, s. 135. 
stycznej idei tworzy się obozy i zataja ich istnienie, uśmiercając nie tylko ludzi, ale także ich najbardziej intymne marzenia o lepszym świecie. Powszechną historię nikczemności można więc sprowadzić do losu wszystkich tych nieszczęsnych idealistów, którzy z Europy ruszyli do "Trzeciego Rzymu“, do Moskwy, i którzy nikczemnie i łajdacko wciągnięci zostali w pułapkę, w której będą krwawić i umierać jako dwukrotnie ranione zwierzęta. Na zbieżności tych dwu punktów - moich doświadczeń z zachodnią inteligencją, bezkrytycznie popierającą tę nikczemność historii, i tego Borgesowskiego, całkowicie nieadekwatnego tytułu - oparła się idea książki Grobowiec dla Borysa Dawidowicza10. (Podkreślenia pochodzą od Autora.)

Czy uzasadnione jest przeciwstawianie przez Kiša metafizyki i zaangażowania, której towarzyszy wzmianka o doświadczeniach zachodniej inteligencji i przywoływanie stosunku francuskiej lewicy wobec faktu istnienia łagrów w ZSSR (problem stosunku wobec terroru i Gułagów w Związku Radzieckim doprowadził do dyskusji, a następnie konfliktu Alberta Camusa i Jeana Paula Sartre'a, który jak większość francuskich intelektualistów - uważał, że prawdę należy przemilczeć w imię „wyższego dobra”? Czy, innymi słowy, opis świata poprzez jego symbolizację, oznacza ucieczkę od rzeczywistości?

W świetle przywołanej definicji zaangażowania Kiša nie powinno tak być. Co więcej, nie powinno tak być, ponieważ metafizyka argentyńskiego pisarza nie ma związku z eskapizmem, lecz jest jedynie wyrazem przekonania o niemożności poznania świata.

Powróćmy do po-etyki Kiša, zawierającej wywodzące się od Platona połączenie estetyki i etyki. Współczesna myśl filozoficzna krytycznie odnosi się do podważenia przez niego statusu poznania zmysłowego, jednak sposób rozumienia tego, co dobre, i tego, co piękne, znajduje w niej akceptację1․ Michel Foucault, wydobywając wspólny korpus problemów, które łączą współczesnego człowieka i starożytnych Greków, mówi o próbie stworzenia „estetyki egzystencji”, a więc o przedsięwzięciu uczynienia z życia ludzkiego dzieła sztuki, o nadawaniu większego znaczenia relacjom z innymi niż poblemom religijnym, o rezygnacji z utożsamiania etyki i instytucjonalnie usankcjonowanego systemu prawnego ${ }^{12}$. Jednak, jak się wydaje, taka postmodernistyczna postawa nie mogłaby być bliska Kišowi, ponieważ, zgodnie z przekonaniami Michela Foucault, intelektualista/artysta musiałby uwolnić się od poczucia realności i zrezygnować z roli osoby, która w imię uniwersalizmu angażuje się w praktyki społeczne i uwalnia od odpowiedzialności za „całość”, czego jednak Kiš jako pisarz jednak nie chciał całkowicie się wyrzec.

${ }^{10}$ D. Kiš, Tražim mesto pod suncem za sumnju. W: idem, Gorki talog iskustva, op. cit., s. 116 i n. Przeł. na polski - S. N. B.

11 Temu problemowi poświęcił w Polsce swoją pionierską monografię Jan P. Huđzik. Jan P. Hudzik, Estetyka egzystencji. Szkice z pogranicza ponowoczesnej etyki i estetyki. Lublin 1998.

12 Zob. drugą część Historii seksualności Michela Foucault z 1983 roku pt. Użytek z przyjemności. M. Foucault, Historia seksualności. Przeł. T. Komendant. Warszawa 1995. 
Kiša, dla którego rozumienie ideologii związane było wyłącznie z represją systemu polityczno-państwowego, odróżniało od postmodernistów szerokie - w ich przypadku - rozumienie ideologicznego charakteru każdego dyskursu.

Literatura postmodernistyczna stanowiła odbicie i komentarz rzeczywistości oparty - według słynnej formuły McHale'a nie na podstawie epistemologicznej, lecz ontologicznej ${ }^{13}$. Właśnie $\mathrm{z}$ tego powodu tak istotnym wydaje się wydobycie różnicy pomiędzy po-etyką Kiša (dla którego możliwa była uniwersalna poetyka i etyka) i poetologii postmodernistów ${ }^{14}$, według których wymiar krytyczny z obszarów zarezerwowanych dla polityki i socjologii przenosi się na wszystkie możliwe sfery życia: naukową, kulturologiczną, filozoficzną, medialną, historyczną, teoretycznoliteracką i artystyczną.

Wydobycie tych dwóch modeli zangażowania jest konieczne. Wydawać by się mogło bowiem, ze projekt ",bycia Środkoweuropejczykiem“ z powodzeniem można by realizować $w$ ramach owego Kišowskiego, modernistycznego modelu oraz w ramach modelu postmodernistycznego. Jednak przykłady, które wskażę, dowodzą, że dyskursy postkolonialne w Serbii w zasadzie "siłują się“ z projektem środkowoeuropejskim, a wspólnym miejscem, punktem wyjścia dla formułowanych zarzutów jest postawa zaangażowania. Analizując więc oskarżenia pod adresem Kiša, można by postawić pytanie o to, które ze świadczących o środkoweuropejskim charakterze cech twórczości tego pisarza nie wpisują się w nowe postkolonialne odczytania Kiša.

Jest niezwykle interesującym fakt, że próby reaktywacji zarzutów sformułowanych przez Jeremicia dokonano w roku 2004. Wówczas to ukazała się w Serbii książka Nebojšy Vasovicia (ur. 1953) - jednego ze znaczących współczesnych serbskich poetów, eseisty i krytyka Lažni car Šćepan Kiš - Fałszywy car (uzurpator) Šćepan Kiš (drugie wydanie: 2005 rok), opatrzona podtytułem Szkic polemiczny o dziełu i ideach Danila Kiša, będącą skandalicznym antysemickim pamfletem, który ukazał się w siedemdziesiątą rocznicę urodzin pisarza. Już sama okładka, przedstawiająca ozdobione odznaczeniami pozbawione twarzy popiersie mężczyzny, nawiązuje do wspomnianej książki Dragana M. Jeremicia. Analiza popełnianych przez Kiša błędów językowych, świadczących o rzekomej nieznajomości elementarnych zasad gramatyki języka serbskiego oraz miernej, określonej przez Vasovicia mianem kiczu, wartości artystycznej jego dzieł, "demaskowanych" jakoby przez autora książki w dalekich od podstawowej rzetelności i uczciwości, opartych na manipulacji i insynuacji, obraźliwych analizach prowadzić miała do zdezawuowania mitu

${ }^{13}$ B. McHale, Od powieści modernistycznej do postmodernistycznej: zmiana paradygmatu. Przeł. M. P. Markowski. W: Postmodernizm. Antologia przekładów. Red. R. Nycz, Kraków 1998, s. 335-377.

14 E. Kuźma, O poetyce negatywnej. Od poetyki do poetologii, od poetologii do metapoetyki. W: Poetyka bez granic. Z dziejów form artystycznych w literarturze polskiej. Red. W. Bolecki i W. Tomasik, t. LXXVIII, Warszawa 1995, s. 41-52. 
pisarza. Choć niewątpliwie fakt ukazania się tej publikacji motywowany był w dużej mierze czynnikami komercyjnymi, jej pojawieniu się przyświecał także inny cel. Znane już z pracy Jeremicia oskarżenia zostały dopełnione $\mathrm{w}$ książce Vasovicia zupełnie nieosadzoną $w$ dziele Kiša i z twórcą tym niemającą żadnych związków, „refleksją" poświęconą Żydom, którzy bogacili się w Ameryce, lub kolaborowali z nazistami, podczas gdy ich bracia ginęli w obozach koncentracyjnych. Przedmiotem zarzutów Vasović była hybrydyczna tożsamość twórcy, który, zdaniem krytyka, m.in. wykorzystywał żydowskie pochodzenie (początkowo wyrzekając się serbskości i przynależności do literatury serbskiej, by zdobyć przychylność Zachodu, a następnie zwracając się ku niej - przechodząc na prawosławie) do kreowania swojego wizerunku.

Dodajmy w tym miejscu, że książka, którą potraktować należy jako skandaliczny incydent, doczekała się ostrej krytycznej oceny i została napiętnowana przez środowisko literackie. Zbliżone stanowisko w tej sprawie zajęli zarówno przedstawiciele samych postmodernistó $\mathrm{w}^{15}$, jak i polemizujące $\mathrm{z}$ nimi pokolenie "młodych"16, które wykorzystało wystąpienie Vasovicia, krytyka debiutującego razem $\mathrm{z}$ postmodernistami i bliskiego im generacyjnie, jako argument $\mathrm{w}$ swojej polemice $\mathrm{z}$ nimi (czy raczej $\mathrm{w}$ ataku na nich) ${ }^{17}$.

Jednak poetyka Danila Kiša nie umknęła uwadze tej nowej generacji serbskich pisarzy i krytyków literackich (często łączą oni obydwie te role społeczne), urodzonych w latach sześćdziesiątych i siedemdziesiątych XX wieku. Pojawili się oni na scenie literackiej w latach dziewięćdziesiątych ubiegłego wieku, w okresie, kiedy postmodernistyczne tendencje $\mathrm{w}$ literaturze serbskiej osiągnęły swoje apogeum. Kiš, jak się wydaje, oskarżony został przez nich niejako pośrednio, jako duchowy patron pokolenia postmodernistów, za sprawą którego jego twórczość doczekała się w Serbii afirmacji (przypomnijmy, że przedstawiciele postmodernistów włączyli się do dyskusji na temat Kiša, opowiadając się po stronie jego poetyki). Atakując pokolenie "potomków” wybitnego twórcy, debiutujących swoimi utworami w latach osiemdziesiatych XX w.) - młodzi nie oszczędzili także ich duchowego ojca - a więc samego Kiša, którego utwory symbolicznie oznaczyły $\mathrm{w}$ Serbii początek postmodernizmu.Wysunęli postulat powrotu tylko do jednego

15 Polemika między Aleksandrem Jerkovem a Nebojšą Vasoviciem: A. Jerkov, Samoubistvo iz oholosti. „NIN” 2005, nr 2826, s. 40 i n.; N. Vasović, Odbrana domaće kišologije. "NIN” 2005, nr 2827, s. 44-46; A. Jerkov, Progon mrtvog pisca. „NIN” 2005, nr 2828, s. 50-52; N. Vasović, Naučna metoda doktora Jerkova. „NIN" 2005, nr 2828, s. 50-52.

${ }^{16}$ Rozmowa Tatjany Čanak z Vasą Pavkoviciem i Vuletą Żuriciem: Napad na mit napisan ofrlje. "Glas javnosti" 14.03.2005, cz. 1, s. 13; Pisac je problem rešio "na brzaka". "Glas javnosti" 15.03.2005, cz. 2, s. 13; Priča o Kišu van književnih okvira. „Glas javnosti” 16.03.2005, cz. 3, s. 13.

17 Obszernie polemikę tę przywołuję w artykule: S. Nowak-Bajcar, Pisarze wobec nacjonalizmu. Dyskusje wokót postaw aktorów społecznych serbskiej sceny literackiej. W: Kultury słowiańskie między postkomunizmem a postmodernizmem. Red. M. Dąbrowska-Partyka. Kraków 2009, s. 160-162. 
z członów Kišowskiej po-etyki - etyki - odrzucając jego poetykę i uznając ją za szkodliwą.

Gest odrzucenia Kišowskiej poetyki „snu” - jak ją nazwali - młodzi uzasadnili potrzebą wkroczenia w świat jawy, rzeczywistości, co umożliwić ma, ich zdaniem, zwrot w stronę (neo)realizmu. Kategoria „snu” - twierdzą - skrywa bowiem niezwykle ważny element postmodernistycznej fantastyki (opartej na intelektualnej grze - zabawie, oddaniu prymatu wyobraźni, marzeniu i odrealnieniu świata), która zyskuje według nich wymiar eskapistyczny - powoduje zanik czujności i uśpienie. Metafora przebudzenia i czujności sygnuje ich usytuowanie na biegunie przeciwstawnym wobec poetyki „uśpionych” postmodernistów i ich duchowego ojca: Danila Kiša.

Zarzut ten jednak może wydawać się zaskakujący, gdy weźmiemy pod uwagę fakt, że w twórczości Danila Kiša ufantastycznienie nie oznacza ucieczki przed rzeczywistością, zaś poetyka snu stanowi jeden z elementów triady: ideologia literatura - etyka, czyli koncepcji literatury, w której najważniejsze miejsce zajęł: rozrachunek ze stalinizmem i Holokaust - ufantastycznienie z wykorzystaniem kodu, który umożliwiał aluzyjne odniesienia do rzeczywistości.

Poetyka Kišowskiego snu, wraz z jego dobitnie przecież podkreślanym postulatem zaangażowania, okazuje się jednak niewystarczająca dla nowego pokolenia. Oznacza bowiem, zdaniem jego przedstawicieli, ontologiczne i epistemologiczne rozchwianie, które uniemożliwia trzeźwą ocenę wydarzeń związanych z ostatnią wojną i rozliczenie się z rolą, jaką odegrała w niej Serbia. Choć przedstawicielom młodego pokolenia przyświeca szczytny cel, to jednak przesłanki, na których opierają oni swoje argumenty, wynikają z niezrozumienia istoty zaangażowania $\mathrm{w}$ myśli postmodernistycznej i przeciwstawiania literatury „czystej” literaturze zaangażowanej. Jednak taka polaryzacja nie jest uzasadniona, tak jak nie jest uzasadnione utożsamianie zaangażowania spod znaku Danila Kiša i zaangażowania postmodernistów: ci ostatni bowiem dokonują demontażu dyskursów, także tego, którym posługiwał się Kiš w swoich wypowiedziach o misji twórcy i sztuki czy potrzebie formy.

Właśnie na tej dekonstrukcyjnej zasadzie opiera się polemiczny aspekt utworów postmodernistycznych, który uniemożliwia ich traktowanie jako czystej formy czy tworów autonomicznych, pozbawionych związków z rzeczywistością - jak argumentują młodzi - oskarżając postmodernistów o to, że ich twórczość explicite nie tematyzuje problemów społecznych i politycznych. Zresztą podobne zarzuty kierowali wobec postmodernistów w latach osiemdziesiątych i dziewięćdziesiątych (podczas trwania postjugosłowiańskich wojen) przywiązani do poetyki realistycznej pisarze tradycjonaliści.

Na taki sposób postrzegania tego problemu niewątpliwy wpływ miała książka Kritička književnost - alternativa postmodernizma (Literatura krytyczna - alternatywa postmodernizmu) Predraga Palavestry, opublikowana w 198318. Jej autor jest jed-

18 P. Palavestra, op. cit. 
nym z badaczy, który w 1983 roku użył pojęcia „postmodernizm” w odniesieniu do (wówczas jeszcze) literatur jugosłowiańskich, dostrzegając ich odrębność w stosunku do postmodernizmu zachodnioeuropejskiego i stanu literatur w krajach bloku socjalistycznego ${ }^{19}$. W opisie literatury posłużył sie on pozaartystyczną kategorią "krytycyzmu“, uzyskujacą w jego refleksji status kategorii etycznej, obejmującej dzieła przynależące do różnorodnych poetyk, których najważniejszym elementem był stosunek do tematów tabu ${ }^{20}$. Jednak najpełniejszy wyraz - stwierdził Palavestra - literatura krytyczna osiąga w realizmie krytycznym, stając się nawet "aktem duchowego oczyszczenia“21.

Chociaż w książce serbskiego badacza znajduje się takie m.in. stwierdzenie: „Serbski postmodernizm bezpośrednio wynika z epoki modernizmu i dialektycznie przezwycięża estetyczną i etyczną tradycję manicheistycznego podziału na sztukę >czystą< i >zaangażowaną<" 22, jednak jego preferencje nie wykraczają poza tę opozycję. Jak zauważa krytyk literacki Tihomir Brajović, polaryzacja polegajaca na przeciwstawianiu "pasywności estetycznego kwietyzmu”, „ucieczki przed rzeczywistością” czy „przesadnego ludyzmu” literatury postmodernistycznej „,etycz-nemu aktywizmowi świadomości" literatury krytycznej oznacza wybór pomiędzy dwiema koncepcjami: jej funkcjonalizacji („Literatura jako alternatywna ideologia”) i autonomizacji („Literatura jako alternatywa dla ideologii, polityki i innych form działań opartych na pragmatyzmie") ${ }^{23}$.

Taka recepcja utworów powstających w latach osiemdziesiątych, z dzisiejszej perspektywy postrzeganych jako postmodernistyczne, nie jest zaskakująca. Podobne oceny pojawiały się $\mathrm{w}$ latach siedemdziesiątych i osiemdziesiątych w odniesieniu do literatury polskiej. Swoistym paradoksem wydaje się fakt, że literatura autotematyczna, powstająca $\mathrm{w}$ Polsce po oficjalnym zerwaniu $\mathrm{z}$ doktryną socrealistyczną w 1956 roku, w latach siedemdziesiątych postrzegana była jako eskapistyczna. W 1980 roku Michał Glowiński określał ją nawet mianem „socparnasizmu”, stwierdzając, że takie utwory były „wytworem i zarazem współczynnikiem sytuacji kulturalnej, która faworyzowała literaturę nieistotną, a więc okaleczoną - także wtedy, gdy osiągała wysoki poziom artystycznego kunsztu"24.

${ }^{19} \mathrm{Z}$ bardziej odległej perspektywy Palavestra łączy postmodernizm w krajach słowiańskich z przełomowym dla Europy rokiem 1989 i upadkiem muru berlińskiego P. Palavestra, Da li Kiš pripada (srpskoj) kritičkoj književnosti? W: Spomenica Danila Kiša. Povodom sedamdesetogodišnjice rođenja. Red. P. Palavestra. Beograd 2005, s. 67-68.

${ }^{20}$ P. Palavestra, Kritička književnost kao oblik očiščenja. W: idem, Kritička književnost. Alternativa postmodernizma. Beograd 1983, s. 203 i n.

${ }^{21}$ Ibidem, s. 211.

22 P. Palavestra, Postmodernizam i književnost. W: idem, Kritička književnost..., s. 17.

23 T. Brajović, Književnost $i$ komentarz. „Književne novine” 1996, nr 926, (15.03.1996), s. 1 i 3.

${ }^{24}$ M. Głowiński, Socparnasizm. W: idem, Rytuat i demagogia. Trzynaście szkiców o literaturze zdegradowanej. Warszawa 1992, s. 160-161. 
Postrzeganie działalności postmodernistów jako autotelicznych gier o charakterze formalistycznym wydaje się nieuzasadnione, bowiem zadaniem współczesnej literatury, jak zauważył serbski badacz Aleksandar Jerkov za Michelem Foucault, nie jest udzielanie odpowiedzi na planie empirycznym, lecz odnajdywanie prawdy w społecznie określonej hierarchii dyskursów (literatura nie rości sobie prawa do reprezentowania "dyskursu prawdy”, lecz do ukazywania "prawdy dyskursu" 25).

Wydawać by się zatem mogło, że takie właśnie przesłanki przyświecały serbskiej krytyczce feministycznej Tatjanie Rosić, która wykorzystuje w swoich pracach zdobycze genderowe, osiągnięcia psychoanalizy, narratologii oraz postkolonializmu. W swojej książce pt. Mit o suršenoj biografiji. Danilo Kiš i figura pisca u srpsrpskoj kulturi26 (Mit doskonałej biografii. Danilo Kiš i figura pisarza w kulturze serbskiej) oskarżyła ona pisarza o to, że jako francuski uczeń (Kiš przebywał we Francji $\mathrm{w}$ okresie przekształcania się strukturalizmu $\mathrm{w}$ poststrukturalizm), utrwalił on prymat męskiego i patriarchalnego paradygmatu w kulturze, czyli - prymat narracji „ojcowskiej”. W chwili, gdy ogłaszano tezy o śmierci figury autora i tezy o jej funkcjonalizacji jako środka kontroli i sprawowania władzy nad społecznymi dyskursami, Kiš uporczywie posługiwał się słowem "pisarz”, pomimo faktu, że jest ono anachronicznym odpowiednikiem słowa "autor", którego figurę "uśmiercił” Roland Barthes w 1968 roku. Jako dowód na poparcie swojej tezy Tatjana Rosić wskazuje fakt, że słowo "pisarz" użyte w mianowniku oraz w przypadkach zależnych pojawia się w twórczości Kiša aż 1022 razy.

Dzieła Kiša, zdaniem Rosić, umocniły nazwę i figurę pisarza - mężczyzny, a afirmacja jego twórczości przez serbskich postmodernistów doprowadziła do upowszechnienia i utrwalenia tego modelu. Postmoderniści, twierdzi Rosić, powinni odznaczać się wrażliwością na problemy kobiecej tożsamości, a model utrwalony przez Kiša, w opinii Rosić, tego kryterium nie spełnia, dlatego też wysuwa ona tezę, że w kulturze serbskiej postmodernizmu po prostu nie ma. Danilo Kiš, twierdzi badaczka, w dziełach i wypowiedziach o nich zawarł różnorodne strategie dekodowania własnej twórczości, które krytycy i badacze posłusznie wykonali, przyczyniając się w ten sposób do wypełnienia "testamentu” duchowego ojca. Przedstawiając źródła swojej twórczości i artystyczne inspiracje (dokonując autoprezentacji) Kiš usytuował się, jak zauważa Rosić, „w imponującej genealogicznej matrycy paternalistycznego porządku literatury europejskiej"27, którą następnie zrekonstruowali badacze jego dokonań. Stało się tak, zdaniem Rosić, ze względu na fakt, że opisu dzieł dokonywano przez pryzmat autobiografii pisarza, a nie uwarunkowań społeczno-kulturowych. Tutaj wskazuje Rosić np. tak niewin-

\footnotetext{
25 A. Jerkov, Istina i moral postmoderne literature. „Književne novine” 1996, nr 923, (01.02.1996), s. 4.

26 T. Rosić, Mit o savršenoj biografiji. Figura pisca u srpskoj kulturi. Beograd 2008.

27 Ibidem, s. 79.
} 
ną i zastanawiającą okoliczność, jaką jest fakt nieistnienia w języku serbskim słowa "pisarka”. Jej zawód określa się w języku serbskim za pomocą określenia: „kobieta-pisarz" - "žena-pisac” lub za pomocą zapożyczenia z języka chorwackiego: „spisateljica”. „W czasach kryzysu patriarchatu - stwierdza Rosić - (...) proza Kiša (...) stanowi akt (ponownego) usankcjonowania prawa do narracji zgodnie z zasada dziedziczenia po mieczu, „z ojca na syna”, zaś figura pisarza staje się figurą heroicznego potomka heroicznych przodków arystokratycznej tradycji europejskiej"28.

Wskazane przeze mnie nowe odczytania twórczości Kiša i roli, jaką odegrał w kulturze, dobitnie wykazują, że przypisana mu przez Dragana Jeremicia etykieta "pisarza bez twarzy” - paradoksalnie - okazuje się trafnym określeniem. I to bynajmniej nie dlatego, że jego twórczość pozbawiona jest oryginalności czy cech swoistych. Do faktu tego przyczyniają się badacze, którzy czynią użytek z dzieł klasyka dla potrzeb własnej opowieści o kolonizowanych. W narracjach tych Kiš staje się głównym oskarżonym w procesie przeciwko sytuacji serbskiej kultury po 1991 roku. Należałoby jednak zastanowić się, dlaczego właśnie Danilo Kiš, kosmopolita i Środkowoeuropejczyk miałby ponosić odpowiedzialność za ten stan?

Paradoksalnie jednak to nie twórczość oraz osoba Kiša, lecz właśnie fakt budowania przez autorów tych narracji zarzutów wobec niego uzasadniają wystawione tej kulturze niepokojące diagnozy. Zaprezentowane sposoby „użycia” wizerunku i twórczości Kiša w dyskursach postkolonialnych potwierdzają jednocześnie tezę Gayatri Chakravorty Spivak o tym, że etyczny cel badań postkolonialnych jest w zasadzie "doświadczaniem niemożliwego ${ }^{29}$.

${ }^{28}$ Ibidem, s. 80. Wyróżnienia pochodzą od Tatjany Rosić.

${ }^{29}$ G. C. Spivak, Krytyka postkolonialnego rozumu. W stronę historii zanikającej wspótczesności. W: Teorie literatury XX wieku. Antologia. Red. A. Burzyńska i M. P. Markowski. Kraków 2007, s. 673. 